\title{
Study of changes in non-stress test following antenatal corticosteroid therapy in preterm pregnancy
}

\author{
Renuka S., Sathiya S.*, Famida A. M., Vijayalakshmi K., Sailatha R.
}

Department of Obstetrics and Gynecology, Chettinad Hospital and Research Institute, Kelambakkam, Kanchipuram District, Tamil Nadu, India

Received: 14 July 2019

Revised: 13 September 2019

Accepted: 30 September 2019

\author{
*Correspondence: \\ Dr. Sathiya S., \\ E-mail: s.sathiya.dr@gmail.com
}

Copyright: (c) the author(s), publisher and licensee Medip Academy. This is an open-access article distributed under the terms of the Creative Commons Attribution Non-Commercial License, which permits unrestricted non-commercial use, distribution, and reproduction in any medium, provided the original work is properly cited.

\section{ABSTRACT}

Background: Preterm birth is the largest unsolved problem in obstetrics and the single most significant cause of neonatal morbidity and mortality. Preterm labour constitutes $5-10 \%$ of pregnancies and is the leading cause of neonatal morbidity and mortality worldwide. It is a major public health problem in terms of loss of life, long term disability (cerebral palsy, blindness, deafness, chronic lung disease). The objectives of this study were to determine whether antenatal corticosteroid administration affects the non-stress test. To evaluate the effect of antenatal steroid on foetal movements. To assess the incidence of respiratory distress syndrome and neonatal mortality after antenatal corticosteroid administration.

Methods: All antenatal cases between 28-32 weeks of gestation judged to be at risk for preterm delivery attending the outpatient department or admitted in a tertiary care hospital, Tamil Nadu during the study period of 3 years.

Results: The present study was undertaken to evaluate the NST for a period of 3 days following antenatal corticosteroid administration and to study the immediate changes in the mother and the foetus. We found out that there was a statistically significant change $(\mathrm{p}<0.01)$ in non-stress test when compared with the pre-betamethasone assay.

Conclusions: Corticosteroids can cause metabolic alterations in mother, short- and long-term effect in the foetus.

Keywords: Antenatal, Corticosteroid, Betamethasone, Foetal movements, Non-stress test, Preterm

\section{INTRODUCTION}

Preterm labour was defined as the onset of regular, painful, frequent uterine contractions causing progressive effacement and dilatation of cervix before 37 completed weeks of gestation from the first day of LMP. ${ }^{1}$ Any infant born before 37 completed weeks should be called preterm. $^{2}$ Betamethasone is one common steroid administered to enhance the foetal lung maturity. Many studies have focused on the steroid influenced regulation of pulmonary surfactant production and related enzymes. Maximum level of circulating serum Betamethasone was found in the mother 1 hour and in the foetus 1-2 hours after treatment. Betamethasone has a half-life of approximately 6 hours and was not detected 48 hours after the last dose. Half-life was predictably longer in the foetal circulation i.e. for 12 hours.

Cord concentrations were consistently lower than maternal samples (cord/maternal ratio: 0:37). All pregnant women between 24 and 34 weeks gestation who are at risk of preterm delivery within 7 days should be considered for antenatal treatment with a single course of corticosteroids. Betamethasone (12 mg IM 2 doses 24 hours apart) or Dexamethasone (6 mg IM 4 doses 6 hours apart). 
The ACOG criteria for a reactive non-stress test is as follows: two accelerations with an amplitude of $15 \mathrm{bpm}$ above the baseline and lasting for 15 seconds within a 20minute period. ${ }^{3}$ During preterm period, CTG shows diminished foetal accelerations due to improper development of cardiovascular system. Mean FHR falls from $160 \mathrm{bpm}$ at 22 weeks to $140 \mathrm{bpm}$ at 27 weeks due to a gradual increase in parasympathetic tone. The foetal stethoscope or fetoscope was described by Hillis in 1917 and by Delee in 1922 .

The introduction of antepartum testing for foetal asphyxia is a major advance in perinatal medicine that has led to a significant and sustained reduction in stillbirths and perinatal morbidity. ${ }^{4}$ The non-stress test (NST) is now widely used for assessment, primarily because it is easy to do, takes little time and lacks contraindications. Early in gestation the foetal heart is predominately under the control of the sympathetic nervous system and arterial chemoreceptors. ${ }^{5}$ The objectives of this study were to study the changes in non-stress test following antenatal corticosteroid therapy in preterm (28-32 weeks). To determine whether antenatal corticosteroid administration affects the non-stress test. To evaluate the effect of antenatal steroid on foetal movements. To assess the incidence of respiratory distress syndrome and neonatal mortality after antenatal corticosteroid administration.

\section{METHODS}

- Linear array real time ultrasound transducer

- Patient fulfilling inclusion and exclusion criteria

- Patient consenting for the study between the gestational age of 28 to 32 .

\section{Methodology}

Prospective cohort study conducted from 2016 to 2019. After obtaining institutional permission. All antenatal cases between 28-32 weeks of gestation judged to be at risk for preterm delivery attending the hospital outpatient department or admitted in hospital during the study period. All cases of preterm labour.

Technically, the test could be stopped after less than 20 mins if adequate reactivity is demonstrated. If reactivity is questionable or there are unusual or worrisome foetal heart rate patterns, monitoring maybe continued up to 90 mins. Maternal smoking and fasting contribute to nonreactivity. The test should be interpreted as soon as possible after performed, while the patient is still present, so that any indicated interventions may be undertaken in a timely fashion. ${ }^{6}$

\section{Interpretation of NST}

Interpretation of foetal heart rate tracing should follow a systematic approach with a full qualitative and quantitative description of the following:
- Baseline heart rate

- Baseline foetal heart rate variability

- Presence of accelerations

- Periodic or episodic decelerations

- Changes or trends of foetal heart rate pattern over time

- Frequency and intensity of uterine contractions.

\section{Inclusion criteria}

- All women between 28- 32 weeks of gestation judged to be at risk of preterm labour with singleton pregnancy

- Threatened preterm labour

- Severe preeclampsia, IUGR, GDM, BOH

- Ultrasound findings in favour of risk of preterm delivery with shortened cervical length.

\section{Exclusion criteria}

- Gestational age less than 28 weeks and more than 32 weeks

- Uncontrolled diabetes

- Symptoms of active infection

- Multiple pregnancy

- Preterm premature rupture of membrane

- Patient in active labour.

Patient diagnosed with risk of preterm delivery between 28-32 weeks of gestation with singleton pregnancy were included in the study. Detailed history taken, thorough general and abdominal examination was done patient admitted and 2 doses of Inj. Betamethasone $12 \mathrm{mg}$ IM was given 24 hours apart. Non stress test repeated after 12 hours (day 1), 24 hours (day 2), 36 hours (day 3) NST taken for a period of 20 mins. In case with a non-reactive NST, in the first 20 mins, NST was repeated after ambulation or mean for a period of another 20 mins. If repeat NST non-reactive, trace will be considered nonreactive. Patients delivered during the study period excluded from the study.

\section{RESULTS}

The study was done in a total of 243 patients of whom 23 patients were lost in follow up. The results were analysed according to the following parameters. Number of patients who were judged to be at risk for preterm delivery. Number of patients in relation to:

Table 1: Age distribution in study.

\begin{tabular}{|ll|}
\hline Mean - 22.96 & Median - 22 \\
\hline Mode - 20 & Standard deviation - 3.58 \\
\hline Minimum - 19 & maximum - 36 \\
\hline Mean - 22.96 & Median - 22 \\
\hline Mode - 20 & Standard deviation - 3.58 \\
\hline Minimum - 19 & Maximum - 36 \\
\hline
\end{tabular}


The age of the patient ranged between 19 and 36 years.

The mean reproductive age group of patients in the study group was 22 years $\pm 3.58 \mathrm{SD}$.

The youngest patient in the study was 19 years.

The elderly primi gravida aged 32 years was included in the study (Table 1).

\section{Socioeconomic status}

Classified according to modified Kuppusamy classification depending upon the per capita income (Table 2).

Table 2: Socioeconomic distribution in the study group.

\begin{tabular}{|lll|}
\hline Socioeconomic status & Frequency & Percentage \\
\hline Upper middle & 31 & $14 \%$ \\
\hline Middle & 42 & $19 \%$ \\
\hline Lower middle & 41 & $19 \%$ \\
\hline Lower class & 106 & $48 \%$ \\
\hline Total & $\mathbf{2 2 0}$ & $\mathbf{1 0 0 \%}$ \\
\hline
\end{tabular}

Booked/unbooked.

The frequency of booked patients were more than unbooked patients (Table 3).

Table 3: Percentage of booked and unbooked patients in the study.

\begin{tabular}{|lll|}
\hline Booked/ unbooked & Frequency & Percentage \\
\hline Booked & 128 & $58 \%$ \\
\hline Unbooked & 92 & $42 \%$ \\
\hline Total & $\mathbf{2 2 0}$ & $\mathbf{1 0 0 \%}$ \\
\hline
\end{tabular}

Table 4: Percentage of different parity in study group.

\begin{tabular}{|lll|}
\hline Parity & Frequency & Percentage \\
\hline Primigravida & 125 & $57 \%$ \\
\hline Gravida 2 & 50 & $23 \%$ \\
\hline Gravida $>2$ & 45 & $20 \%$ \\
\hline Total & $\mathbf{2 2 0}$ & $\mathbf{1 0 0 \%}$ \\
\hline
\end{tabular}

\section{Parity at reporting}

Out of 220 patients, $57 \%$ (125 cases) comprised of primi gravid (Table 4).

Gestational age at reporting in weeks.

Study population consisted of 63 cases (28\%) in gestational age group between 32 and 34 weeks, 157 cases $(72 \%)$ between 30 - 32 weeks (Table 5).
Table 5: Percentage of gestational age reported in study.

\begin{tabular}{|lll|}
\hline $\begin{array}{l}\text { Gestational age at } \\
\text { reported }\end{array}$ & Frequency & Percentage \\
\hline $28-30$ weeks & 63 & $28 \%$ \\
\hline $30-32$ weeks & 157 & $72 \%$ \\
\hline
\end{tabular}

Table 6: Indication for corticosteroid.

\begin{tabular}{|lll|}
\hline Diagnosis & Frequency & Percentage \\
\hline IUGR & 17 & $8 \%$ \\
\hline Cervical incompetence & 15 & $7 \%$ \\
\hline Severe pre-eclampsia & 23 & $10 \%$ \\
\hline BOH & 10 & $5 \%$ \\
\hline Placenta previa & 16 & $7 \%$ \\
\hline Threatened preterm labour & 82 & $37 \%$ \\
\hline GDM & 29 & $13 \%$ \\
\hline Others & 28 & $3 \%$ \\
\hline
\end{tabular}

Threatened preterm labour was the commonest indication of antenatal corticosteroid therapy (Table 6).

\section{Changes in NST}

- Before Betamethasone

- Reactive: 214 cases

- Non-reactive: 6 cases.

Changes in NST after Betamethasone (Table 7).

Table 7: Ratio of NST changes before and after betamethasone.

\begin{tabular}{|llll|}
\hline Days & CHI square & P-value & $\begin{array}{l}\text { Odds ratio } \\
(\mathbf{N R} / \mathbf{R})\end{array}$ \\
\hline Day 1 & 1.1 & 0.292 & 2.34 \\
\hline Day 2 & 3.015 & 0.083 & 4.114 \\
\hline Day 3 & 8.344 & 0.004 & 9.22 \\
\hline
\end{tabular}

Even though NST changes in maximum number of patients was found on day $1(30.5 \%)$ and day $2(33.6 \%)$, patient who continued to have non-reactive NST even on day 3 achieved a statistical significance ( $p$ value $<0.05$ ). This study was done in 243 patients in a period of 3 years out of which 23 patients were lost to follow up. The mean age group in this study was 22 years. People in lower socioeconomic were more when compared to other classes. The frequency of booked patients was more than unbooked. Primi gravida were more than the multi gravid. Threatened preterm labour was the commonest indication for antenatal corticosteroid therapy and comprised of $37 \%$. NST showed a non-reactivity in 67 cases on day 1, 74 cases on day 2 after Betamethasone. Around 13 cases continued to have non-reactive NSTs even after day 3 on Betamethasone out of which 9 had reactive traces on day 4 . Types of changes analysed were 
baseline heart rate, baseline variability, acceleration and deceleration.

\section{DISCUSSION}

Senet et al, concluded that compared with the control day, long and short term foetal heart rate variability were reduced on days 2 and $3(\mathrm{p}<0.01)$ in one third of cases, the foetal heart rate transiently decreased below the normal range. ${ }^{7}$

Rotmensch S, et al, concluded that Betamethasone causes profound but transient suppression of foetal heart rate parameters. $^{8}$

In 1969, Liggins et al, investigated the initiation of parturition in sheep, observed that lambs born preterm after iatrogenic in utero exposure to corticosteroids had less respiratory distress. Pathologically more mature appearing lungs and survived longer than control lambs. ${ }^{9}$ A study conducted by Liggins in 1972, concluded that antenatal Betamethasone decreased the incidence of respiratory distress syndrome by $30 \%$. In the subsequent study done in 1973 and $1977 .{ }^{10}$ Liggins found almost $50 \%$ reduction in neonatal mortality when antenatal steroids were administered

Crowley's Cochrane review showed a statistically significant reduction in RDS in preterm born before 32 weeks of gestation. ${ }^{11}$

In December 1994, ACOG endorsed the findings of the NIH consensus which concluded that antenatal corticosteroid clearly led to the reduction in neonatal mortality, respiratory distress syndrome and intraventricular haemorrhage and they strongly recommended that antenatal corticosteroid therapy to be given to all women at risk of preterm premature delivery within 7 days and NIH reconvened a consensus conference on antenatal corticosteroid therapy in August $2000 . .^{12-14}$

Hon $\mathrm{E}$ et al found that the foetal heart rate was the first biophysical variable that could be reliably recorded and assessed. ${ }^{15}$

Kelly MK, Schneider EP et al, in a prospective study done in 84 patients concluded that there was a significant change in the non-stress test following antenatal corticosteroid therapy. ${ }^{16}$

Mulder EJ et al, studied the short-term effect of maternal Betamethasone administration on 13 women at high risk of preterm delivery ( 26 to 32 weeks). ${ }^{17}$ Betamethasone was administered in 2 doses with 24 hours apart after control recording have been made. After 2 doses of Betamethasone, FHR variation was considerably reduced ( $\mathrm{p}<0.01$ ) but returned to normal after treatment was discontinued.
In comparing all the previous study with the present study, all studies showed a similar outcome with a decrease in baseline variability $(\mathrm{p}<0.01)$.

\section{CONCLUSION}

Maternal Betamethasone causes transient change in the fetal heart rate variability and baseline heart rate $(\mathrm{p}<0.001)$. Unfortunately, the incidence of preterm labour has changed very little over the last 40 years and uncertainties still persist regarding the best strategies for its management. The introduction of maternal antenatal glucocorticoids treatment to accelerate foetal lung maturity has allowed us to significantly reduce associated mortality and morbidity. It is important to recognize the changes in the fetal heart rate is a physiological response to maternal corticosteroids. It is important to be aware that decrease in foetal heart rate variability can occur after Betamethasone and it should not be assumed that the foetus is hypoxic, which will otherwise lead to unnecessary delivery of the healthy preterm foetus.

\section{Funding: No funding sources \\ Conflict of interest: None declared}

Ethical approval: The study was approved by the Institutional Ethics Committee

\section{REFERENCES}

1. Howson CP, Kinney MV, Lawn J. March of Dimes, PMNCH, Save the Children. Born Too Soon: the global action report on preterm birth. WHO; 2012.

2. Spong CY. Defining term pregnancy: recommendations from the Defining "Term" Pregnancy Workgroup. JAMA. 2013;309:2445-6.

3. Antepartum foetal surveillance, In: Practice Bulletin 9. American College of Obstetrics and Gynecology; 1999.

4. Vintzileos AM. Antenatal assessment for the detection of fetal asphyxia: an evidence-based approach using indicating-specific testing. Ann NY Acad Sci. 2000;90:137-50.

5. Renou P, Warwick N, Wood C. Autonomic control of foetal heart rate. Am $\mathrm{J}$ Obstet Gynecol. 1969;105:949.

6. Myrick T, Harper DM. Principles of nonstress testing in pregnancy. J Family Pract. 1996;43:443-8.

7. Senat MV, Minoui S, Multon O, Fernandez $H$, Frydman R, Ville Y. Effect of dexamethasone and betamethasone on fetal heart rate variability in preterm labour: a randomised study. BJOG: An Int J Obstet Gynaecol. 1998;105(7):749-55.

8. Rotmensch S, Liberati M, Vishne T, Celentano C, Ben-Rafael Z, Bellati U. The effect of betamethasone and dexamethasone on fetal heart rate patterns and biophysical activities, A prospective randomized trial. Acta Obstetr Gynecol Scandinavica. 1999;78(6):493-500.

9. Liggins GC. Howie RN. Prevention of respiratory distress syndrome in premature infants by 
antepartum glucocorticoid treatment. In: Villee CA, Villee DB, Zuckerman J eds. Respiratory distress syndrome. London: Academic press; 1973:369-380.

10. Howie RN, Liggins GC. Clinical trials of antepartum Betamethasone for prevention of respiratory distress in preterm infants. In: Preterm labour: Proceedings of the fifth study group of the Royal College of Obstetricians and Gynecologists London; 1977:281289.

11. Crowley P. Prophylactic corticosteroids for preterm birth. Cochrane Database Syst Rev. 2000;(2):CD000065.

12. National institutes of health consensus developement conference statement. Am J Obstet Gynecol. 1995;173:246-52.

13. ACOG Committee Opinion. Committee on Obstetric Practice: Antenatal corticosteroid therapy for fetal lung maturation. 1994:147.

14. National Institutes of Health Consensus Development Conference Statement. Antenatal corticosteroids revisited: repeat courses. 2000.
15. Hon EH, Quiligan EJ. The classification of foetal heart rate. Conn Med. 1967;31:779-84.

16. Kelly MK, Schneider EP, Petrikovsky BM, Lesser ML. Effect of antenatal steroid administration on the foetal biophysical profile. J Clin Ultrasound. 2000;28:224-6.

17. Mulder EJ. Transient reduction in foetal activity and heart rate variability after maternal Betamethasone administration. Early Hum Dev. 1994;36(1):49-60.

Cite this article as: Renuka S, Sathiya S, Famida AM, Vijayalakshmi K, Sailatha R. Study of changes in non-stress test following antenatal corticosteroid therapy in preterm pregnancy. Int $\mathbf{J}$ Reprod Contracept Obstet Gynecol 2019;8:4435-9. 